\title{
DEATHS OF BLACKS IN POLICE CUSTODY: A BLACK BRITISH PERSPECTIVE OF OVER 50 YEARS OF POLICE RACIAL INJUSTICES IN THE UNITED KINGDOM
}

\author{
Shaka Yesufu \\ Department of Research and Development \\ University of Limpopo \\ Turfloop, Sovenga, Republic of South Africa \\ Shakazulu17@yahoo.co.uk
}

\begin{abstract}
On 25 May 2020, the death of an unknown Blackman named George Floyd in the Minneapolis United States has led to a wave of global protests worldwide. The United Kingdom was not left out of these protests. The deaths of black people in police custody are not a new unfortunate phenomenon in the United Kingdom. The author looks at some of these deaths in the United Kingdom from a historical perspective, relying on both racial typologies theorists on one side and the responses, provided by Afrocentric theorists on race over time, on the other side. The author relies on several case studies of black deaths and secondary sources, arguing that racism can be held responsible for most of these killings by the police. The research findings are encapsulated in the trio unfortunate incidents of slavery, colonialism, and apartheid. These incidences have metamorphosed over time, becoming a social stigma black people wear from cradle to grave. The author suggests that police officers who murder black people and hide behind the wearing of uniforms should not be given immunity from justice. The author debunks the myth, suggesting that the life of a black person is often portrayed as worthless by whites folks. More findings are that both black lives and every human being's lives matter with great intrinsic value. No life must be wasted under the guise of policing. The right to life unarguably remains the most fundamental human right, which the state must protect at all times. Without the protection of life, all other fundamental human rights become meaningless.
\end{abstract}

Keywords: race, racism, police, deaths, custody, accountability, social justice.

DOI: $10.21303 / 2504-5571.2021 .001981$

\section{Introduction}

The loss of life is not what anyone would want or expect to happen to their loved ones. It becomes even more shocking when it occurs in tragic and unexpected circumstances under the watchful eyes of the police. This article is divided into three parts. In the first part of the article, the author looks at some case studies of black deaths in police custody in the United Kingdom, exploring the circumstances, surrounding their deaths, taking into consideration that racism may play a contributory part to some of such these deaths. In the second part of the article, the author looks at some racial typologies, which works may have played a contributory factor towards the inferiorising of the black race. The article also looks at some of the responses from Afrocentric writers, debunking some of the stereotypical and racists myths, peddled for centuries about black people. The inferiorisation of the black race is contextualised from the three unfortunate accidents of history, found in these trio eras: Slavery; colonization and apartheid. An era where black people were treated as sub-human beings, depicted, caricatured, lampooned, and seen as bastardize species on earth. The author explores some Eurocentric writers/philosophers who helped to propagate the white race supremacy over time. In the third part of the article, the authors provide the reader with some recommendations that will reduce black deaths in police custody to the barest minimum. In other to have a balanced view of black deaths in police custody, it is important to bear in mind that there are also other possible causes of deaths in police custody, namely: natural causes, overdoses, suicides, injuries received before detention, medical condition, deliberate self-harm, restraint methods, intoxication and positional asphyxia [1]. The author for the remit of this article will only explore the issue of race as a contributory factor to black deaths in police custody. Police officers in the United Kingdom continue unlawfully and forcefully restrain black detainees despite numerous reports, stopping them from doing so [2].

According to research on police procedures, officers are responsible for the safety and wellbeing of the suspects they hold in custody. Leigh et al. [3] argued that "the police are expected to detain individuals they believe have broken the law. However, they also have to protect any indi- 
vidual they have arrested or detained for their safety". It is this dual responsibility that makes any death in police custody disturbing and potentially controversial. For families of the deceased, it can be particularly distressing to learn that someone they were close to has died and that this happened whilst they were in police custody. It can be argued, that the police as an apparatus of the state was created to protect the white and affluent good folks from the potential likely attack from members of the dangerous classes, predominately black folks [4].

Aim of research. The research has three aims. First, the research was carried to explore and highlight the racial injustices, suffered by black people. To debunk some of the myths, surrounding the stereotypical view of black people who many believe are created to endure sufferings and hardships. Third, to hold claim that racism forms a greater explanation as to why a high proportion of blacks are killed in custody.

\section{Materials and Methods}

The author employed the use of case studies because deaths in police custody are a very complex and contentious research topic. The case study was used in this research to extend the authors' policing knowledge and experiences, gained both as a serving police officer in the United Kingdom and the Republic of South Africa. Each of case by case study was supported by contextual analysis, which is one of the characteristics of a qualitative study. The author consulted extensive literature of previous studies relating to the topic of deaths of black in police custody. Emergent thematic headings arose, which were coded according to their relevance to the research topic.

\section{Result}

In this part of the article, the researcher looks at the following concepts: police custody; specific case studies and analysis; police racism; racial typologies versus Afrocentric theoretical frameworks; list of recommendations to eradicate deaths of black in custody; and the researcher draws his conclusions.

\section{1. Police Custody}

The Police and Criminal Evidence Act (PACE) 1984 set out the rules and procedures for dealing with detained persons in custody in England and Wales. Rules for the detention of suspects in police custody are set out in the Police and Criminal Evidence Act 1984. Code C of the Act deals specifically with detention, treatment, and questioning of persons by the police.

The London Metropolitan Police Service has over 76 custody suites, designated under PACE for the reception of detainees [5]. During the arrest of suspects, police officers usually make use of restraint measures on suspects to physically bring them under control. These methods are designed to be used during confrontations or volatile situations. Reasonable force may be used when necessary. For example, in a situation where officers are facing immediate danger and potential risk to their lives, the use of minimum force under the Criminal Law Act 1967 becomes justified. Police officers are allowed to use reasonable force, which restrains a person, during arrest or detention (under section 117 PACE 1984).

A high number of people who die in police custody or specifically following the use of restraint are from minority ethnic groups; this inevitably leads to allegations of racism (PCA, 2002). A closer look at some of my case studies is presented in this article, for example, the murder of the following persons of African origin namely: Ibrahima Sey, Shiji Lapite and Frank Ogboru, and Winston Rose, Brian Douglas, Wayne Douglas, Christopher Alder, and Frank Duggan.

First, the author presents circumstances, surrounding the death of Ibrahima Sey, suggesting that there are some elements of police racism in all these deaths.

\section{2. Case studies of blacks deaths in police custody}

\section{2. 1. Ibrahima Sey's death in police custody}

Ibrahima Sey, a Gambian asylum seeker, was killed in the early hours of 16 March 1996 after having been taken from his home to the Ilford Police Station in East London. He was suffering from a mental illness, the effects of which have been described variously by the labels "excited 
delirium" or "acute exhaustive mania." The police arrived at his home in response to a call for help from his wife, Amie, as a result of his strange behavior, which alarmed her to the extent that she jumped out of a window, leaving the two infant children behind with him. He came out of the house to be conveyed to the Ilford Police Station without any struggle on his part. At the police station, Mr Sey's refused to enter the custody suite while handcuffed, he was forcibly restrained by up to nine police officers and sprayed with CS until he collapsed in a corridor. In the custody suite, some four to six officers continued to hold him down by his head, arms, and legs - including two officers with their feet on his legs - for the next 15 minutes or more. It was while being held in this position that he suddenly became relaxed and, after being checked, was found not to be breathing. In consequence, an ambulance was called, and the ambulance crew described their surprise and shock to find Mr Sey still on the floor of the custody area with his hands still handcuffed behind his back even though he was showing no signs of life. They took him to the hospital where he was pronounced dead. The inquest jury decided that Mr Sey had been unlawfully killed. The Crown Prosecution Service made a preliminary decision not to prosecute the officers, involved in Mr Sey's death, before the inquest. The Metropolitan Police had already announced that no disciplinary action was being taken against the officers involved [6].

\section{2. 2. Analysis of Ibrahima Sey's death in police custody}

Several factors persuaded the author to conclude that racism played a contributory factor to $\mathrm{Mr}$ Sey,s death. First, he was handcuffed, forcibly restrained by up to nine police officers, and sprayed with CS spray. Do we need nine police officers to restrain one individual who is handcuffed? This is where the myth of black people possessing extraordinary strength comes into play. The police officers, involved in this murder, choked the life out of Mr Sey because physical confrontation during arrest provided them the opportunity to do so. The author believes that the police officers, involved in the incident, acted unlawfully and no doubt acted in violation of Ibrahima Sey's rights to life. Next, the author looks at the circumstances, surrounding the death of Shiji Lapite.

\section{2. 3. Shiji Lapite's death in police custody}

Shiji Lapite died after being stopped by Stoke Newington police officers for "acting suspiciously." The cause of death was asphyxia from compression of the neck, consistent with the application of a neck hold. At the inquest, officers admitted kicking Mr Lapite in the head, biting him, and placing him in a neck hold. Pathologists' evidence and post mortem reports revealed bruising and abrasions to his body, showing that he had suffered between 36 and 45 separate injuries and that his larynx and neck were bruised and the cartilage in his voice box was fractured. Police officers could not explain the disparity in injuries, received by Mr Lapite and themselves, as was apparent from the evidence available. Officers said there was a violent struggle, during which $\mathrm{Mr}$ Lapite had attempted to strangle one of them. A Home Office pathologist said that serious doubt must be thrown on this allegation, given the absence of any marks on the officer's neck.

The inquest jury returned a unanimous verdict that Mr Lapite had been unlawfully killed, demonstrating that they did not believe the police version of events. However, in August 1996 the Crown Prosecution Service (CPS) announced their decision not to prosecute the officers, involved in the case, although, on the first occasion that a jury heard evidence about their conduct, the inquest jury unanimously decided they had 'unlawfully killed' him.

\section{2. 4. Analysis of Shiji Lapite's death in police custody}

The author believes that the death of Lapite was not justified and that the force, used against him, did not fall under the remit of the Criminal Law Act 1967. The discovery of between 36 and 45 separate injuries to the victim's body during the post mortem examination is sickening enough to suggest to me that the police had not used minimum force. It can be argued, that the use of disproportionate force by the police causes members of the black community to suspect that nothing else but police racism is responsible for such deaths. And to compound matters, the perpetrators of 
these callous, extrajudicial murders are not being brought to justice. Next, the author looked at the death of Mr Frank Ogboru, a black detained person of African origin.

\section{2. 5. Frank Ogboru's death in police custody}

On 26 September 2006, a Nigerian man, Mr Frank Ogboru died after being arrested by police officers in Plumstead London. CS spray was used and he was restrained by at least four officers before he became unwell and stopped breathing. Attempts were made to resuscitate him, the London Ambulance Service was called and he was taken to Queen Elizabeth Hospital where he was pronounced dead. The Independent Police Complaints Commission (IPCC) then sent a file to the Metropolitan Police Service for their recommendation as to whether any disciplinary action was proposed [7].

A Crown Prosecution Service (CPS) (2008) press release made it clear that the CPS would not prosecute any of the police officers, involved in Mr Ogboru's death, because of insufficient "the arrest itself was lawful...In carrying out the arrest the officers were entitled to use such force as was reasonable in the circumstances that existed at the time. Police training is that once officers have achieved control of the arrested person they should get him to his feet, but experts on restraint who have watched the video believed that the officers never achieved control until moments before $\mathrm{Mr}$ Ogboru lost consciousness". The two officers managed to take Mr Ogboru to the floor, but were still unable to get the handcuffs on him and it was only with the arrival of two more officers that the officers were able to get the handcuffs secured.

While being restrained, Mr Ogboru was clearly in distress and this is confirmed by the witnesses present and a mobile phone recording. Because Mr Ogboru continued to struggle, the officers did not release their hold on him. Other officers arrived and at about the same time one of the officers, restraining Mr Ogboru, became concerned and the officers realised that he had collapsed. Despite strenuous efforts, all attempts at resuscitation failed. The pathologist gave "asphyxia during restraint" as the cause of death." [8].

\section{2. 6. Analysis of Frank Ogboru's death in police custody}

We have been informed that four officers were involved in the arrest process of Frank Ogboru and that a physical struggle ensued between the police and the victim. It was also mentioned, that during the arrest, the four police officers refused to release the hold on him until he died.

In Britain, the law of cruelty to animals does not allow to put a dog to sleep in this inhumane way, and yet what we see sometimes done by police officers to members of the black community, lives, wasted in the glare of the eyes of the public, is very shocking! The author argued that this incident is similar to what happened with George Floyd in the Minneapolis United States on May $25^{\text {th }}, 2020$. Even when he pleaded to a police officer Derek Chauvin, he still would not allow him to breathe. Many black people who died in police custody have suffered the same fate as George Floyd, but their voices were never heard. They died in silence and their killers walked scotfree. Next, the author discusses the death of Winston Rose.

\section{2. 7. Winston Rose's death in police custody}

Winston Rose, a 27-year-old amateur boxer, died while being taken into custody by the police in Leyton, East London, in July 1981. Rose had previously spent some time in a mental hospital, suffering from schizophrenia, but had recovered. Mr Rose had been made redundant in May 1981 and became depressed, imagining that his house was bugged and that people were pointing at him in the street. His wife, Thora, had arranged for doctors and social workers to visit him at home to persuade him to take medication. When they visited, Mr Rose started shouting at them - although there was no physical violence. Initially, Mr Rose locked himself in a neighbour's garden shed when he realised that the police had come to pick him up. It was alleged, that he kicked one of the police officers. At this point, another officer picked up a dustbin lid and charged with it at Mr Rose, who allegedly grabbed the lid and hit the first officer over the head with it. The second officer then wrestled Mr Rose to the ground and put 
a hold on him, which caused intense pain to the bridge of his nose. The rest of the officers joined in to hold Rose down, and he was held in a headlock for several minutes until, in the words of one officer, his eyes were "bulging" and he had been "pacified." He was then carried unconscious and with vomit in his mouth to a police van and driven away. Ten minutes later, when police realised that Mr Rose had stopped breathing, at the time they called for medical help. The ambulance personnel who attended were at first prevented from giving the correct form of resuscitation because he was handcuffed and the key had been lost. Despite the inquest verdict of unlawful killing, the Director of Public Prosecutions decided in 1982 that none of the police officers, involved in Rose's detention, was to be prosecuted. The Rose's family began civil proceedings against the police and, in 1990, on the day the case was due to be heard in the High Court, eight and half years after his death, they received a settlement of $£ 130,000$ from the Metropolitan Police. But no form of apology was ever issued by the police.

\section{2. 8. Analysis of Winston Rose's death in police custody}

From the above-given scenario, the holding of Winston Rose in a headlock until his eyes were bulging out by police officers constitutes a callous murder as the author understands it. Officers involved should have been charged for the murder of the victim. Second, the loss of handcuff keys, which delayed resuscitation of the victim, should have led to charges of professional negligence, brought against the officers concerned. Next, the author looks at the unlawful death of Brian Douglas in the hands of the police.

\section{2. 9. Brian Douglas's death in police custody}

Brian Douglas was arrested in Clapham in South London not long after midnight on May $3^{\text {rd }}$, 1995. During the arrest, he was hit on the head with an issued American-style long-handled baton. The two police officers who arrested him claimed to have been acting in self defense because Mr. Douglas had allegedly been carrying a CS gas canister and a knife. This was contradicted by eyewitnesses who gave evidence at the inquest. The officers also claimed that Mr. Douglas had been struck a blow on his upper arm, which went over his shoulder and hit his neck. Mr. Douglas was not taken to hospital until more than 12 hours after he was injured.

No disciplinary action was taken against either officer after a fully supervised Police Complaints Authority (PCA) investigation and no charges were brought by the Crown Prosecution Service.

\section{2. 10. Analysis of Brian Douglas's death in police custody}

First, the hitting of Brian Douglas's head with the American Styled baton needs to be assessed against two factors to establish whether such force was justified or not. Did Mr Douglas possess a threat to the lives of the officers concerned? Was the plea of self defence justified in this circumstance? From the above-given scenario, without being judgmental, the author believes that $\mathrm{Mr}$ Douglas did not pose a threat to police officers, not in the plea of self defence, justified by police officers concerned under the prevailing circumstances of the arrest, explained above. Even if he did pose a threat, Mr Douglas should not have been denied access to medical attention as far as the author is concerned. It is the rationale behind such denial that encourages members of the black community to conclude that racism is responsible for such callous acts by police officers. Mr Douglas as we are informed was placed in the cell after he was hit on his head with a police baton. He vomited in his cell and after 12 hours has elapsed before he was taken to the hospital. Was this time delay justified? What do the Police And Criminal Evidence Act 1984 (PACE) say about the treatment of detained persons? Was PACE followed concerning this incident? The author is not convinced that PACE procedures were properly followed on this occasion. PACE does not suggest that a detained person who has been struck in the head with a police baton, vomits in custody, is denied access to medical attention for over 12 hours. This is where the allegation of police racism by the families of bereaved becomes understandable and justified. Next, the author looks at the death of Christopher Alder. 


\section{2. 11. Christopher Alder's death in police custody}

The police have acquired a reputation for protecting serving officers by allowing them to take early retirement before criminal proceedings are instituted by bereaved families. As reported in the Guardian newspaper in 2004, four or five officers at the centre of a long investigation into the death of a black paratrooper Christopher Adler had resigned. These officers were in their late $30 \mathrm{~s}$ and early 40s, and they were all cleared of manslaughter. The names of the five officers, accused of the murder of Mr Christopher Alder, are as follows: PS Dunn, PC Barr, PC Dawson, PC Blackley, and PC Ellerinngton. Mr Alder, a 37-year-old black paratrooper of Caribbean origin was arrested by the police after he fought outside at a nightclub in Hull on 1 April 1998. He was conveyed to the Queen Garden police station Hull. After about 13 minutes, he was seen lying with his face down and was pronounced dead.

\section{2. 12. Analysis of Christopher Alder's death in police custody}

The video, played before the jury, showed officers saying that Mr Alder was faking injury when he was genuinely grasping for breath. The error of judgment, made by the police statement of feigning of injury, may have been caused Christopher Alder's life. Next, the author presents the death of Mr Frank Duggan.

\section{2. 13. Frank Duggan's death in police custody}

Mr Frank Duggan is a black male of Caribbean origin that was shot dead by police in London. His deaths led to a spontaneous violent disturbance spreading across the United in an unprecedented manner. While some may argue that the riots especially the looters have nothing to do with Mr Duggan's death, they were opportunists who saw a breakdown of law and order to carry out their nefarious activities under the guise of protesting against the police.

On Thursday 4 August 2011 at about 6.13 pm. Mr Duggan was reportedly shot dead by police in Tottenham, North London. Mr Duggan was a passenger in a minicab, he receives a single shot to the chest during an operation, involving Scotland Yard Officers Trident gun crime unit. It was first reported in the news, that Mr Duggan was killed because he shot first at the police who were trying to arrest him. A version of events, which turned out to false as events unfolded, following a ballistic test from the stray bullets, lodged in one of the officer's radios, that turned out to belong to the police and not Mr Duggan's as was widely claimed in the media [9].

\section{2. 14. Analysis of Frank Duggan's death in police custody}

The author is tempted to ask at this juncture what do the police gain for trying to mislead the public, especially when it comes to the deaths of minorities. The case of misleading the public by the police is not a new phenomenon in the United Kingdom, the murder of Jean Charles de Menezes, a 27-year-old Brazilian, shot dead mistaken for a terrorist on 22 $2^{\text {nd }}$ July 2005, is another good example of how the police have made efforts to mislead the British public in the past. The impact of these incidents means that there is an issue of loss of trust and confidence from Londoners. It is difficult to have an effective police service when members of the public they serve and protect have lost their collective trust and confidence.

The author argues that the labeling and stereotyping of blacks as people of extraordinary strength have provided a basis for some of the myths, entertained by the police and the wider British society. One such myth is that black people are more aggressive and violent than white people or any other race. If this view is subconsciously or consciously shared by the wider society, what then can we expect from the police, who have been socialized into these norms? Racial antagonism of course!. It can be rightly argued and supported by scientific evidence, that a child imbibes the norm, found in his/her social learning environment. The police go out looking for the aggressive and violent members of the black communities, if necessary provokes them into becoming angry. It is argued, that some white police officers are happy to be involved in a physical confrontation when arresting angry black suspects in comparison to white suspects, committing the same crime [10]. Next, the author highlights the tragic killing of Ms Joy Gardner. 


\section{2. 15. Joy Gardner's death in police custody}

Ms Joy Gardner was a Jamaican mature student, living in Crouch end London United Kingdom. Ms Gardner was detained after a police and immigration raid on her home in 1993. She was restrained with handcuffs and leather straps and gagged with a13 foot length of adhesive tape, wrapped around her neck. Unable to breathe, she collapsed and suffered brain damage due to asphyxia. She was placed on life support, but died following a cardiac arrest four days later. In 1995, the three police officers (John Burrell, Colin Whitby, and Sergeant Linda Evans), responsible for Ms Gardner's, faced trial and were all acquitted.

\section{2. 16. Analysis of Joy Gardner's death in police custody}

It is very difficult for blacks who die in police custody to get justice in the United Kingdom. British police have enjoyed immunity from prosecution for decades. It is high time such unlawful and inhumane immunity be discarded with. Police officers who deliberately kill black or white citizens must face the full wrath of the law. The author argued that police officers who killed Ms Joy Gardner have not yet evaded justice because the ultimate verdict rests in the eternal court of our creator.

\section{2. 17. Police racism in relation to death of blacks in police custody}

The author's understanding of racism is found in the definition provided in the Concise Oxford English dictionary [11].

"The belief that each race or ethnic group possesses specific characteristics, abilities, or qualities that distinguish it as inferior or superior to another such group. Discrimination against or antagonism towards other races or ethnic groups based on such a belief"

Lawrence Blum [12] identified three types of racism namely: personal racism "consist in racist acts, beliefs, attitudes, and behaviour on the part of the person. Social or social-cultural racism comprises racist beliefs, attitudes, and stereotypes widely shared within a given population and expressed in cultural and social modes, such as religion, popular entertainment, advertisements, and other media."

The author argues that police officers are not impervious to the prejudicial treatment, stereotyping, and labeling of Black Minority Ethnic communities as deviants by the members of the wider British society. The police are a microcosm of society and the police culture of machismo is a part of the police canteen culture. This is a culture that is deeply rooted in male chauvinist beliefs, for example, that women are unsuited to the job, as indeed are black people. The police culture of machismo does not allow them to back down when their authority is challenged by members of the Black Minority Ethnic community. They may resort to violence to establish their position of power and control [13]. The level of strain, suffered by members of Black Minority Ethnic communities, living in Britain due to social deprivation and marginalization, makes them easy targets for the police to stop and search. When police officers stop members of Black Minority Ethnic communities, they are more likely to be doing so because of their colour rather than their class. Colour takes precedence over a person's class. Class becomes a secondary issue. The class factor only comes into play after a black person has been stopped by the police [14]. The police can determine, via communication, to which class the person belongs. It is difficult to tell, which class a person belongs to without interaction. We cannot rely on a person's appearance alone to draw these conclusions.

In Holdaway's [15] analysis of canteen culture, he reported the use of derogatory language, such as "Spade" and "Coon" to refer to black people as part of everyday policing.

First, the author presents some of the definitions of police culture, made available by previous police researchers. Reiner [16] defines police culture as "the values, norms, perspectives and craft rules, which inform police conduct". Meanwhile Chan [17]. defines police culture as 'informal occupational norms and values, operating under the rigid hierarchical structure of police organizations'. According to Manning [18], police culture is 'accepted practices, rules, and principles of conduct that are situationally applied, and generalized rationales and beliefs'. What we can deduct from the above definitions is that 'the police hold a distinctive set of norms, beliefs, and 
values, which determines their behaviour, both amongst themselves and operationally out on the streets' Loftus [19].

The author argues that, over the years, black people have claimed that the deaths of blacks in police custody have been characterised by certain racial elements. They have also argued that those police officers, responsible for the deaths, are not charged or brought to justice (see Fitzgerald and Sibbitt [20]; Leigh et al. [3]. They have claimed that this illustrates the low-value society has placed on a black person's life [21]. The author explores some of the work of Inquest in this research. Inquest is a British non-governmental organization, set up to provide support for bereaved families and friends of those who have died in police custody. It also provides a free legal service to bereaved families. Inquest aims to raise awareness about controversial deaths and to campaign for change to improve investigative processes, increase the accountability of state officials and avert future deaths (Inquest 1998: 2). According to Bethan Loftus [19], 'racism has been identified as one of the most central and problematic features of police culture. Black and minority ethnic officers, working within white-dominated organisations, have articulated their experiences of isolation and discrimination within policing organisations' Holdaway and Barron [22]; Martin [23].

Robert Reiner argues that racial disparity within the British criminal justice system is rife. The data on the disproportionate black representation in the criminal justice process constitute the bedrock of information, around which the flourishing debate about race and criminal justice has come to be constituted [24]. According to Bowling and Phillips [25], 'People, whose skins are not white, have typically been seen as a problem for the social order in the United Kingdom, their very presence giving cause for concern. A line of argument ,made earlier by Gilroy [4], also supports the view of the unnecessary moral panic associated with being black and living in Britain. He convincingly argues that

"Blacks have been identified as the dangerous classes, whose criminal culture erupts periodically, affecting the healthy Britishness of the working-class communities they once invaded. The popular conceptions of their criminality, embodied in the mugger, the Rasta and, latterly, the rioter have been defined and amplified by the police...grounded in commonsense knowledge of alienness in authoritarian legality."

Reiner [26], wading into the stereotypical view of blacks in the United Kingdom, argues that "the crucial source of police prejudice is societal racism, which places ethnic minorities disproportionately in those strata and situations, from which the police derive their property. The structural feature of police-ethnic minority relations bolsters any prior prejudice police officers have".

The Reiner's argument is built on the premise that police racism is partly societal racism and partly pervasive police canteen culture. Chan [17] argues that police prejudice "can easily lead to harassment and community resentment, evidenced by hostility from members of minority communities"

Gordon [27] took it a step further, he argues that "there can be no doubt that police officers are racist, but the British state defined black people as a problem, both through immigration laws to keep them out, and through measures of "integration", designed to manage the "problem" already here. In this management of the "black problem", the police have played a key role...They have not acted as mere servants of the state, doing what was asked of them. They offered their definition of black people as a policing problem, a definition which both reflected the institutionalized racism of the state and society at large and reinforced it".

Hall [28]; Gilroy [4]. One can clearly understand why police officers on patrol might lookout for a certain kind of person (black and suspicious) who fits the description of "police property". The use of discretion is cleverly used as a shield to cover up police deviant and racist behaviour, sometimes deployed during stop and search; in some circumstances, reasonable grounds for carrying out such stops may never have existed and, thus, were unjustified. Yesufu [9, 29, 30]. Next, the author introduces some of the misleading arguments, posited by racial academics over time.

3. 2. 18. Racial Typologies theoretical framework $v$ Afrocentric theoretical framework

The black race was depicted by racial typologists as cursed by God (Ham - descendants of biblical Noah) as explained by the Hamitic hypotheses conceptual framework as a pillar of the 
belief that God in the bible (Genesis 9:20-27) placed a curse on all black Africans and condemned them to eternal slavery (Gobineau [30]; Fanon [31, 32]; Gilroy [4]; Goldenberg [31]. Felder [33]. The equation of the black race with sinfulness, barbarity, and bestiality persisted for centuries unchallenged. The sub-human status, ascribed to black people, was used as a justification for slavery, colonialism, and apartheid. One can safely argue that the debasement of black people is embedded in this trio of unfortunate historical annals. In his reconstruction of the changing "idioms of race" in the course of the evolution of Western thought on this issue, Michael Banton [34]. points to the idea of descent as the oldest understanding of this term. "The Old Testament provided a series of genealogies, by which it seemed possible to trace the peopling of the world and the relations, which different groups bore to one another" [35]. In this explanation, differences of colour among people could be viewed either as part of God's design for the universe and, as such, simply indicated separate ancestries of human beings, which were neutral in their value implications, or, more commonly in Christian teachings throughout the Middle Ages, they reflected the divine curse on Ham's descendants who were thus perceived as "other" and "excluded" from the establishment of Christianity in Europe and this continent's subsequent development, black people were systematically represented as radically "othered," and "inferiorized" by European traders, missionaries, slave dealers and colonialists who visited Africa and came into contact with its native inhabitants [36]. It was through the information they disseminated, that some of the dominant racist views, held by the Europeans about back people, have become widespread and, over time, taken for granted. Fanon [28, 37]; Gilroy [4] on the history of the emergence of derogatory perceptions of blacks in Europe and, later, in North America.

Two nineteenth-century British and French writers, Charles Hamilton-Smith (1775-1859) and Arthur de Gobineau (1816-1882) produced justifications of racial superiority of whites and degradation of blacks, Hamilton-Smith described the white race as

"A veritable paragon, able to endure the greatest vicissitudes of temperature in all climates to emigrate, colonizes, and multiplies in them, with the sole exception of the positive extremes... He alone of the family of mankind has produced examples of free and popular institutions... He has ascended to the skies, descended into the deep, and mastered the powers of lightning. He has instituted all the great religious systems of the world. The black stock had nothing to contribute since the good qualities, given to him by the bounty of nature, have served only to make him a slave" [38].

Gobineau likewise argued that everything great, noble, and fruitful in the works of man on this earth springs from the Aryan family. He described it as: "the irreconcilable antagonism between different races and cultures [as] established by history... Such is the lesson of history. It shows us that all civilization derives from the white race that none can exist without its help and that society is great and brilliant only so far as it preserves the blood of the noble group that created it, provided that this group itself belongs to the most illustrious branch of our species" [30].

David Hume (1711-1776), the renowned $18^{\text {th }}$-century philosopher, wrote "I am apt to suspect the Negroes and in general all the other species of men...to be naturally inferior to the whites" (Hume 1739-1740; 1748 [39]; and 1751 [40]). As Memmi [41] simply puts it 'Racism appears not as an incidental detail, but as a substantial part of colonialism. It is the highest expression of the colonial system' then and now.

Social Darwinism encourages modern-day racism. It is a theory, based on the justifications of social inequalities in our society. Proponents of this theory argue that differences in ability between individuals and groups are translated into hierarchical social structures with dominant and subordinate groups, accommodating such hierarchies that are coded in the human genome. They argued that blacks have lower social status than whites because it is claimed, that blacks, on average, lack genes for a cognitive function that is mostly possessed by whites. The achievement of high status, wealth, and power is a consequence of intrinsic intellectual ability, which black people do not possess, according to results, gathered from IQ testing (Herrnstein and Murray [42]. This argument is not only misleading, but also deeply flawed with racist skewed undertones. Until this oppressive constellation of cultural and socio-economic circumstances African Americans found themselves as broken down, Dubois argued, the Negroes were faced with a no-win situation and 
had only three choices: (i) submit permanently to an inferior position with a painful "double consciousness", trying to negotiate two separate, black and white worlds; (ii) die out; or (iii) emigrate. The African-American sociologist Oliver Cox, noted as one of the earliest Marxist theorists to analyze race relations, proposed a different explanatory approach. In his books Caste, Class, and Race: A Study in Social Dynamics [43] and Foundations of Capitalism [44], Cox located the origins of racial prejudice in the European expansion from the end of the fifteenth century. Cox analyzed both the Atlantic slave trade and the plantation slavery in the Americas in the past and the contemporary patterns of racial domination and exclusion around the world. Cox explained the ubiquitous racism in the United States of his day as being due to the position of black workers as the most harshly exploited labourers within the American capitalist system. John Rex in his Race Relations in Sociological Theory [45], like Cox, traces the phenomenon of racism to the historical process of the colonial expansion of Europeans - here, the English - and explains the persistently subordinate position of blacks in terms of their relation to the currently dominant means of production. Frantz Fanon differs from the early theories because of his passion to decolonize the Africa continent. He was not just a theorist, but took an active part in the Algerian revolution against France's imperialism [46]. Fanon was concerned about the exploitative tendencies of the European colonialists who visited Africa under cover of a civilizing mission. Fanon warned that "colonialism is not satisfied merely with holding a people in its grip and emptying the native's brain of all form and content. By a kind of perverted logic, it turns to the past of the oppressed people and distorts, disfigures and destroys it" [37].

On the diasporic front, Fanon is concerned about the low status, ascribed to blacks, living in Western societies. They are sometimes treated with contempt, suspicion, and hostility and are denied access to the mainstream of Western societies. In particular, the author was persuaded by Stuart Hall's argument that 'few people have begun to understand the stress, placed on them or their complex needs and expectations or their particular vulnerability' [28].

One can understand the level of strain members of minorities' communities have felt over the years due to the rejection into the mainstream of British society. Black people are more likely to feel the strain of society, resulting to build up anger and frustration, arising out of not given equal access to opportunities in Britain. Sometimes Black people may result to crimes because they have got nothing to lose from a society that does not treat them fairly as citizens and they may get involved in crime as a means of registering their protests against the unfair treatment they have had to put up with over the years. Lea and Young [47]; Gilroy [48, 49].

Fanon also provided a provocative explanation of how the Negro is perceived in a post-war, Western, white-dominated society. He argued that "everywhere the Negro turns in Europe, he is dehumanized by white folks ... The white man is convinced that the Negro is a beast, if not the length of the penis, and then it is the sexual potency that impresses him...The 'other' will become the mainstay of his pre-occupation and his desires. The women invariably view the Negro as the keeper of the impalpable gate that opens into the realm of orgies; of bacchanals of delirious sexual sensation ..."

Fanon [31]

In an interesting insight into the Western imperial culture, Lola Young [50] argued that much of the literature, produced during the late nineteenth century, was repleted with supposedly well-informed references to the character of Africans - such as the notion of atavism, founded on the belief that the 'primitive' people of Africa constituted an earlier stage of human development which directly reflected the white supremacy conceptions of race [31, 50]. It can be argued, she proposed, that beneath the present-day post-modernist pleasure, associated with cinema and, especially, its representations of the "natives [e. g. Tarzan] in their natural state of being", there lurks a message about the civilized whites' cultural superiority over the wild and dangerous 'others.' [50].

In contemporary British society, a contemporary case in point, showing that black people continue to be seen as the 'othered' having 'sexual potency', was portrayed by the British media', referring to Olympic champion Linford Christies 'Lunch Box", representing what Fanon described above as derogatory reference to black people as 'bacchanals of delirious sexual sensation'. The 
author concurs with Fanon and added that black people need to be appraised more for other sterling human qualities rather than be evaluated for sexual prowess that may or not even exist.

\section{2. 19. Recommendations}

The author recommends the following:

a. Rigorous background and criminal checks for police new intakes.

b. Race and diversity modules should be made a compulsory part of the police training manual.

c. Psychometric tests to deter entrants with racialist supremacy views

d. Rigorous personality tests like the Myer Briggs Type personality test must be administered for recruits.

e. The establishment of effective police complaints and disciplinary units.

f. An effective judiciary that defends and propagates the rule of law.

g. A whistleblower protection scheme must be put in place.

h. History of black culture, migration, explaining how and why black people came to live in the diaspora, should become part of the school's curriculum.

i. Police officers, found guilty of deaths of the detained person(s), must forfeit their pension and gratuity.

j. Tough sentences for police officers, found guilty of the murder of any citizen.

\section{Conclusion}

It is disturbing to note, that the same police officers who are meant to protect us all are found wanting in terms of the use of force during arrests. The author calls this kind of a misnomer, or a "paradoxical tragedy" because it is difficult to reconcile how the police can hold a claim to serve and protect all citizens when our brothers and sisters are sent to their early graves. Article 2 of the Convention on Human Rights states that we have a right to life. It also asserts, that the state has a positive duty in law to protect the lives of everyone in its jurisdiction and that any force used must be commensurate with the level of threats faced - that is, reasonable force. Police officers should be fully cognizant of these pieces of legislation and the sanctions that go with them. They should be accountable for their actions if they carry out unlawful acts against any citizen. It is the lack of proper police accountability that makes it possible for the police to act unlawfully in breach of PACE. Police accountability would ensure that things are done properly and appropriate sanctions applied. It is not surprising today why black people's lives do not matter to white racist supremacist police officers who hide behind their uniforms to commit crimes with impunity. It is not also surprising to see a white police officer, filled up with hatred and resentment to the extent of not even deterred or understand clearly when a black person says they cannot breathe they are not trying to feign injuries, but appealing to be allowed to breathe in the air they need to survive. The author concludes that all human beings must strive hard enough to find lasting solutions to this police callousness and madness that shames us all as men and women in uniform. To this end, the author calls for all police organizations to get rid of the rotten apples and murderers in their rank and file. In doing so, will be restoring respect, credibility, and confidence to their police profession. For over five decades since David Olawale the first recorded black person to die in British police custody in 1969, many other black detainees have seen their lives cut short in the hands of the police. Their deaths were never accounted for in-law or heard globally, but remained within the United Kingdom. The author argues that one black death in police custody is one life too many. It should not be happening at all. Every human being lives matter with great intrinsic value. No life must be wasted under the guise of policing. The right to life unarguably remains the most fundamental human right, which the state must protect at all times. Without the existence of life, all other fundamental human rights become meaningless and nugatory.

\section{Dedication}

The author dedicates this article to all black detainees who have lost their lives at the hands of the British police whilst in custody and did not get justice. Although all of them were not men- 
tioned in this article, it is hoped, that they have all been given a voice. The author pays a glowing tribute to all their family members, relatives, and loved ones who have endured and suffered losses, resulting from their tragic deaths. We remember them all today as victims of the British racial injustices over the years. History will always remember them because none of them died in vain. Rest in eternal peace.

\section{References}

[1] Independent Police Complaints Commission (2007-2010) Deaths in Police Custody. London: IPCC.

[2] Taylor, D. (2021). Police Restraint Contributed to Leon Briggs Death. The Guardian. Available at: https://www.theguardian. com/uk-news/2021/mar/12/police-restraint-contributed-leon-briggs-death-inquest-jury

[3] Leigh, A., Johnson, G., Ingram, A. (1999). Deaths in Police Custody: Learning the Lessons: Police Research Papers 26. London: Home Office, 94. Available at: https://www.researchgate.net/publication/265199084_Deaths_in_Police_Custody_Learning_the_Lessons/stats

[4] Gilroy, P.; Scraton, P. (Ed.) (1987). The myth of black criminality. Law, Order, and the Authoritarian State, 1, $107-120$.

[5] Her Majesty's Inspectorate of Constabulary (HMIC) (1997). Winning the Race: Policing Plural Communities. London: Home Office.

[6] Inquest (1998). Death in Police Custody of Ibrahima Sey. London: Inquest.

[7] Athwal, H., Bourne, J., Wood, R. (2010). Racial Violence: The Burning issue. Paper No. 6. London: Institute of Race Relations.

[8] Wilson, D., Ashton, J., Sharp, D. (2001). What Everyone in Britain Should Know about the Police. London: Blackstone Press, 212.

[9] Independent Police Complaints Commission (2005). Step-by-Step How to Make a Complaint Against the Police.COM/10. London: IPCC.

[10] Yesufu, S. (2013). Discriminatory Use of Police Stop-and-Search Powers in London, UK. International Journal of Police Science \& Management, 15 (4), 281-293. doi: http://doi.org/10.1350/ijps.2013.15.4.318

[11] The Concise Oxford English Dictionary (2008). Oxford University Press, 1728.

[12] Blum, L. (2002). Racism: What It Is and What It Isn't. 2002. Studies in Philosophy and Education, 21 (3), 203-218. doi: http:// doi.org/10.1023/a:1015503031960

[13] Punch, M. (2009). Police Corruption, Deviance. Accountability and Reforming Policing. Devon: Willan, 294.

[14] Yesufu, S. (2017). The Reality of Crime and Policing in the United Kingdom and South Africa. Cape Town: Reach Publishers. Available at: https://nlsa.on.worldcat.org/oclc/1028638304

[15] Holdaway, S. (1983). Inside the British Police: A Force at Work. Oxford: Basil Blackwell.

[16] Reiner, R. (1992). The Politics of the Police. London: Harvester Wheatshea, 334.

[17] Chan, J. (1997). Changing Police Culture: Policing in a Multicultural Society. Cambridge University Press, 238.

[18] Manning, P. K. (1989). Occupational Culture. Encyclopedia of Police Science. Vol. 1. New York: Garland, 481-506.

[19] Loftus, B. (2009). Police Culture in a Changing World. Oxford: Oxford University Press, 258.

[20] FitzGerald, M., Sibbit, R. (1997). Ethnic Monitoring in Police Forces: A Beginning, Research Study 173. London: Home Office, 109. doi: http://doi.org/10.1037/e451742008-001

[21] Brooks, D. (2006). Steve and me: my friendship with Stephen Lawrence and the search of Justice. London: Abacus, 312.

[22] Holdaway, S. (1991). Race relations and police recruitment. The British Journal of Criminology, 31 (4), 365-382. doi: http:// doi.org/10.1093/oxfordjournals.bjc.a048135

[23] Bulmer, M., Solomos, J. (1999). Racism. Oxford: Oxford Readers, 463.

[24] Reiner, R. (1989). Politics of the Police. Oxford: Oxford University Press.

[25] Bowling, B., Phillips, C. (2007). Disproportionate and Discriminatory: Reviewing the Evidence on Police Stop and Search. Modern Law Review, 70 (6), 936-961. doi: http://doi.org/10.1111/j.1468-2230.2007.00671.x

[26] Reiner, R. (2010). The Politics of the Police. Oxford: Oxford University Press.

[27] Gordon, P. (1983). White Law. London: Pluto Press, 159.

[28] Hall, S., Critcher, C., Jefferson, T., Clarke, J., Roberts, B. (1978). Policing the Crisis: Mugging, the State, and Law and Order. Palgrave, 425.

[29] Yesufu, S. (2020). Racial Discrimination in the London Metropolitan Police Service. SunKrist Sociology and Research Journal, 1 (1), 1-8. doi: http://doi.org/10.46940/ssrj.01.1005

[30] Gobineau, J. A. (1853). The Inequality of Human Races. Wikisource. Available at: https://en.wikisource.org/wiki/The_Inequality_of_Human_Races

[31] Goldenberg, M. D.; Salman, J., West, C. (Eds.) (1997). The Curse of Ham: A Case of Rabbinic Racism? "Struggles in the Promised Land". Oxford: Oxford University Press, 161. 
[32] Fanon, F. (1959). The Wretched of the Earth. Hamondworth: Penguin.

[33] Felder, H. C. (1990). Troubling Biblical Waters: Race, Class and Family. New York: Orbis.

[34] Banton, M. (2020). The Idea of Race. London: Routledge Taylor Francis, 198. doi: http://doi.org/10.4324/9780429311703

[35] Banton, M. (1991). The Race Relations Problematic. The British Journal of Sociology, 42 (1), 115-130. doi: http:// doi.org/10.2307/590837

[36] Fanon, F. (1952). Black Skin, White Masks. Pluto Press, 323.

[37] Fanon, F. (1964). Towards the African Revolution. New York. Groove Press, 209.

[38] Smith, H. (1848). The Natural History of the Human Species.

[39] Hume, D. An Enquiry Concerning Human Understanding, Wikisource. Available at: https://en.wikisource.org/wiki/ An_Enquiry_Concerning_Human_Understanding

[40] Hume, D. (1751). An Emerging Enquiry Concerning the Principles of Morals. London: A. Millar.

[41] Memmi, A. (1974). The Colonizer and the Colonized. London: Souvenir Pres.

[42] Hernstein, R. J., Murray, C. (1994). The Bell Curve. Intelligence and Class structure in American Life. New York: Simon \& Schuster, 845.

[43] Cox, O. C. (1948). Caste, Class and Race. A Study in Social Dynamics. New York: Monthly Review Press, 624.

[44] Cox, O. C. (1959). The Foundations of Capitalism. New York: Philosophical Library, 500.

[45] Rex, J. (1970). Race relations in Sociological Theory. London: Weidenfield and Nicholson, 161.

[46] Fanon, F. (1963). The Wretched of the Earth. Harmondsworth: Penguin

[47] Lea, J., Young, J. (1984). What is to be done about law and order? Harmondsworth: Penguin, 284.

[48] Young, L., Sessay, K. (2005). Write black, write British: from post-colonial to black British Literature. Hansib Publications, 384.

[49] Gilroy, P. (2013). There Ain’t No Black in the Union Jack. Michigan: Florence Taylor and Francis Arbor, 416. doi: http:// doi.org/10.4324/9780203995075

[50] Young, L. (2000). What is Black British Feminism? Women: A Cultural Review, 11 (1-2), 45-60. doi: http:// doi.org/10.1080/09574040050051415

Received date 14.06.2021

(C) The Author(s) 2021

Accepted date 23.07.2021

Published date 30.07.2021

This is an open access article under the

Creative Commons CC BY license

How to cite. Yesufu, S. (2021). Deaths of blacks in police custody: a black british perspective of over 50 years of police racial injustices in the United Kingdom. EUREKA: Social and Humanities, 4, 33-45. doi: http://doi.org/10.21303/2504-5571.2021.001981 